\title{
The Early Eneolithic burial ground at Ekaterinovsky Cape in the forest-steppe Volga region
}

\author{
Arkadii Korolev $^{1}$, Anna Kochkina ${ }^{2}$, and Dmitry Stashenkov ${ }^{2}$ \\ 1 Samara State University of Social Sciences and Education, Samara, RU \\ arkorolev@gmail.com \\ 2 Samara Regional History Museum of P. V. Alabin, Samara, RU \\ archeo@list.ru
}

\begin{abstract}
The Ekaterinovsky Cape burial ground is located on the territory of the Samara region of Russia on the left bank of the River Volga. The excavation of the burial ground was carried out in 2013-2018. During this time we studied 100 graves, including sacrificial sites with ceramics of collar type and sacrificial complexes. Most of the skeletons were in an extended position on their backs. There are some skeletons on their backs with legs bent at the knees, secondary burials and separate burials of skulls. Ochre was used. The inventory included beads made from shells, stone products, animal teeth, bones and horns. There we distinguished graves with stone sceptres and zoomorphic rods made from the horn. The burial ground belongs to the Samara culture and dates from the second half of the $6^{\text {th }}$ millennium $B C$.
\end{abstract}

KEY WORDS - Early Eneolithic; Samara culture; Ekaterinovsky cape burial ground

\section{Zgodnje eneolitsko grobišče na rtu Ekaterinovski na območju gozdne stepe ob Volgi}

\begin{abstract}
IZVLEČEK - Grobišče na rtu Ekaterinovski se nahaja na območju samarske regije v Rusiji na levi strani reke Volge. Izkopavanje grobišča smo izvedli med leti 2013 in 2018. Odkrili smo 100 grobov, vključno s prostori žrtvenih obredov s keramiko z ovratniki in žrtvenimi kompleksi. Večina skeletov je bila v iztegnjenem položaju na hrbtu. Nekaj skeletov je položenih na hrbet s skrčenimi nogami, nekaj je tudi sekundarnih pokopov in ločenih pokopov lobanj. Tudi okra je bila uporabljena. Med najdbami so jagode, izdelane iz školjk, kamniti izdelki, živalski zobje, kosti in rogovi. Prepoznali smo tudi pokope s kamnitimi sceptri in zoomorfnimi palicami iz roževine. Grobišče sodi v kulturo Samara in datira $v$ drugo polovico 6. tisočletja pr. $n$. št.
\end{abstract}

KLJUČNE BESEDE - zgodnji eneolitik; kultura Samara; grobišče rt Ekaterinovski

\section{Introduction}

The Ekaterinovsky Cape burial ground is located on the territory of the Samara region of the Russian Federation on the left bank of the Volga River (Fig. 1). The burial ground is located near the village Ekaterinovka and occupies the northern edge of a small elevation in the middle part of the cape, which is formed by a sharp bend of the Bezenchuk River (Fig. 2).
The burial ground was opened in 2013 by Anna Kochkina and Dmitry Stashenkov (Kochkina 2015. 495-496). Further excavations lasting from 20132018 were carried out by an expedition of the Samara Regional History Museum and Samara State University of Social Sciences and Education under the guidance of the authors of the article. The total area 
of the excavation was $318 \mathrm{~m}^{2}$. There were 101 graves that we studied, only one grave (No. 12) relates to a later time. The burial ground contains valuable materials with regard to burial rites and inventory, anthropological and genetic composition of the buried people, emergence of cattle breeding in the Volga region, social relations and chronology of the late Neolithic and Eneolithic. Many artefacts from the inventory of graves are unique and are of great importance for the analysis of primitive art and religion. In this article we present new materials and research results of this burial ground.

\section{The stratigraphy}

Stratigraphy and description of layers: 1) turf up to $10 \mathrm{~cm} ; 2$ ) a layer of activity from the last century up to

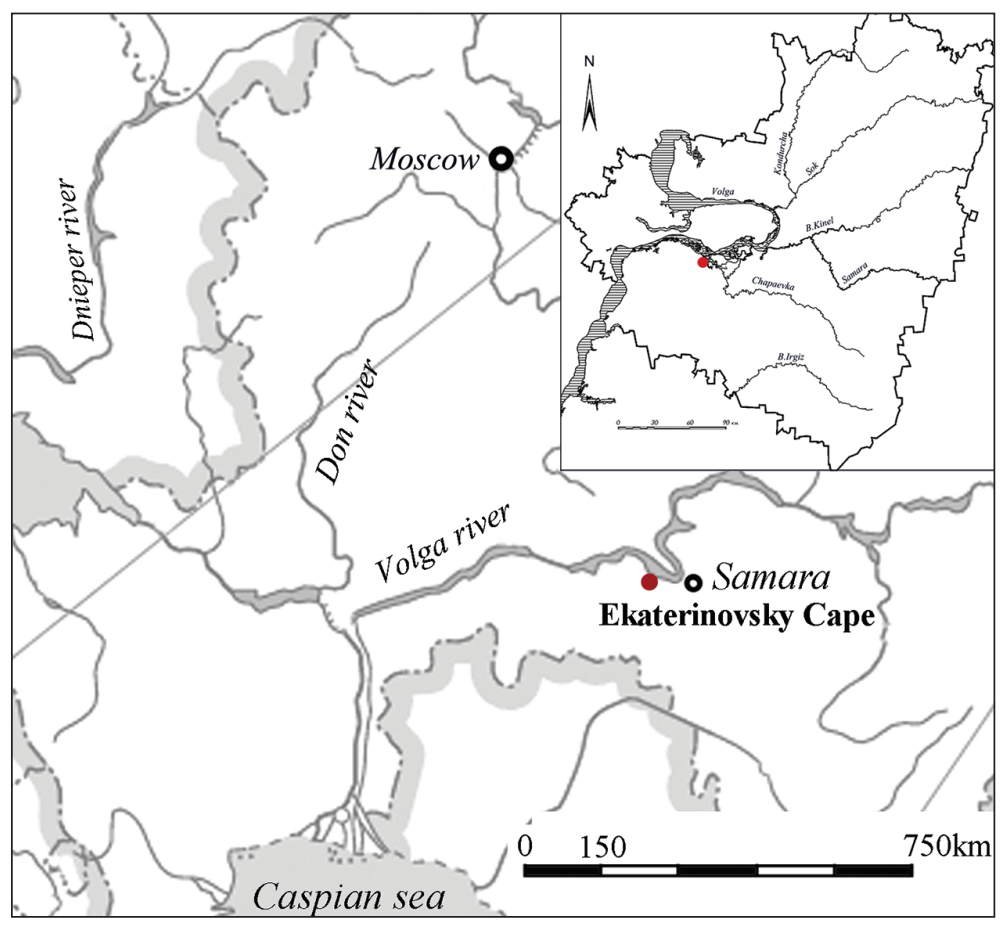

Fig. 1. Map of the location of the Ekaterinovsky Cape burial ground. $40 \mathrm{~cm}$; 3) black dense loam, up to $40 \mathrm{~cm}$; 4) browngrey dense loam, up to $25 \mathrm{~cm}$; 5 ) brown continental clay (Fig. 3). The graves are in the bottom of the layer of brown-grey loam and in the upper part of the continental clay. Both layers are disturbed by shrewmice. The northern part of the burial ground was destroyed during road reconstruction works. In this part the depth of graves was $5-20 \mathrm{~cm}$ from the surface, in the central, southern and western parts it increased to $50-80 \mathrm{~cm}$, and in the east it reached $120 \mathrm{~cm}$. The filling of the grave pits, as a rule, did not stand out against the background of the surrounding soil. Sometimes a darker spot of filling was recorded in the place of the burial pit, but it usually did not coincide with its edges. Ochre was a good ed (Fig. 4). Among the graves located on the periphery of the burial ground, ochre is less common and in smaller quantities. In some graves ochre was not used at all.

\section{The funeral rites}

As a rule, the graves are individual (Fig. 5), but some paired ones were also found, for example, 70-71 (Fig. 6). Sometimes the placement of graves is in several layers. For example, three graves $(63,64,68)$ were located one above the other in three layers. Some cases of partial overlapping of one skeleton by another have also been recorded; $e . g$., part of grave 31 is covered by grave 20 located above it (Fig. 7). marker of graves or sacrificial sites. The ochre-coloured soil or clusters of ochre grains indicated a burial pit or sacrificial site. The degree of colouring of skeletons with ochre is different. Graves with 'rich' and numerous inventories were plentifully covered with ochre. Often there were only single spots or grains of ochre in the graves. The pit of grave 31 was localized by spots of red ochre and darker filling. Due to the bright colour of the soil grave 79 was reveal-

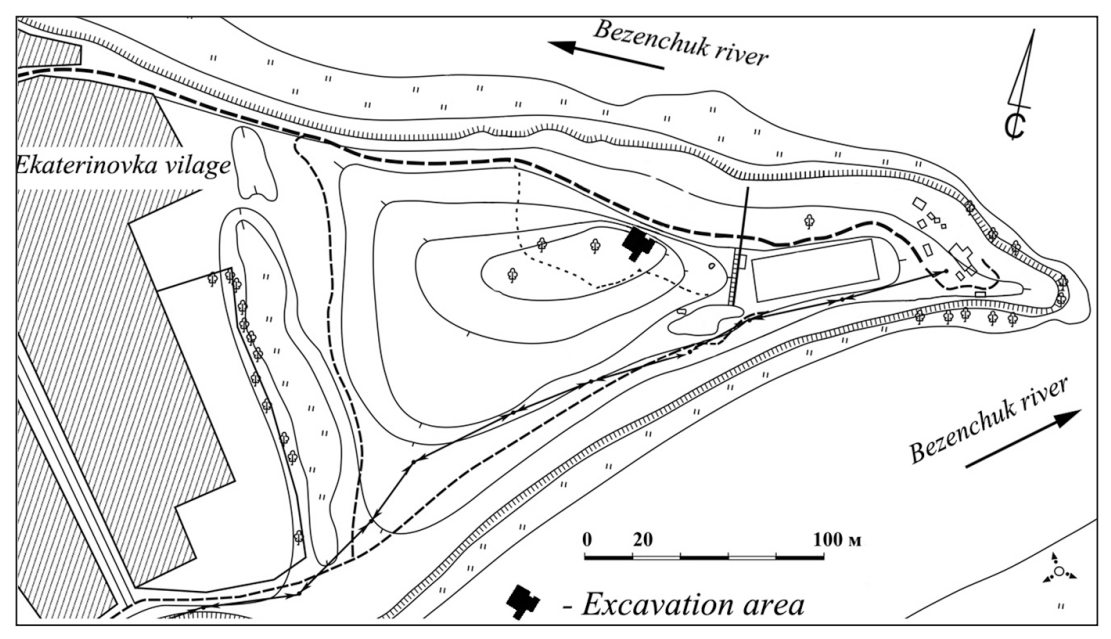

Fig. 2. Plan of the Ekaterinovsky Cape burial ground. 
These observations provide us an opportunity to clarify the sequence of formation of the burial ground. There are groups of compactly located graves with equally oriented skeletons. Often such groups form rows that are not very even and differ in the number of graves (Fig. 7). Cases of early grave infringement are rare. It can be assumed that the graves were designated by some signs. However, no traces of gravestones were found. Some of the graves, mainly in the central and eastern parts of the burial ground, do not form rows. They are represented by whole ske-

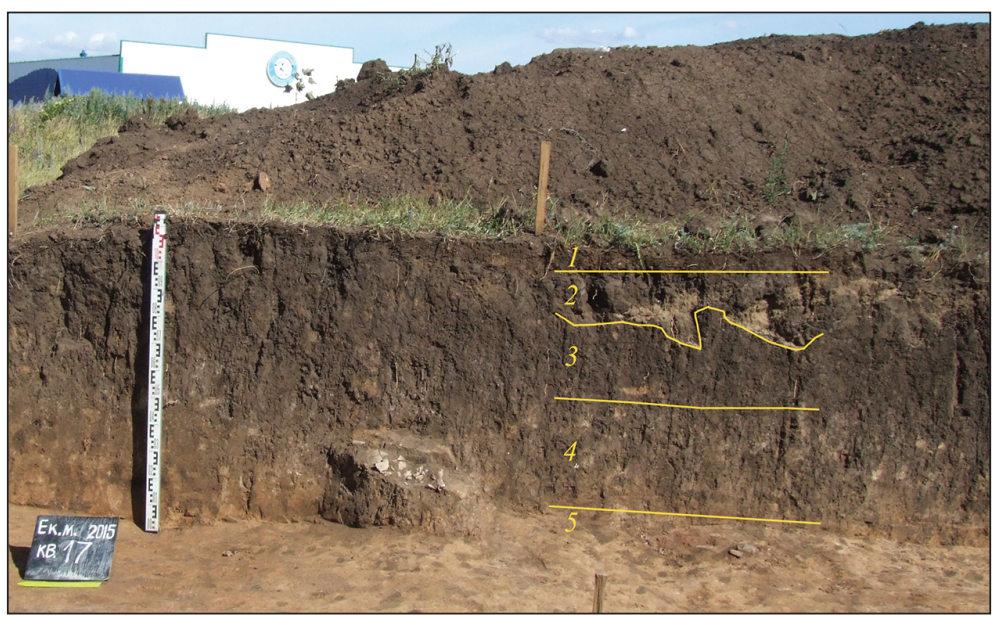

Fig. 3. The excavation profile along the N-S line. letons and their fragments, as well as only by the skulls.

The position of the skeletons provides a basis for the selection of ritual groups. It should be noted that in the destroyed graves it is not always possible to trace the positions of skeletons. However, skeletons extended on their backs dominate the burial ground. Arms are usually extended along the skeleton, while hands are located near the pelvic bones or lie on the pelvic bones. They constitute the first group (Fig. 8). The sculls of skeletons are oriented to the south-east, east, northeast, and sometimes to the north.

The second group of skeletons is characterized by crouched position on the back with the knees raised. This group is smaller and not so uniform. The position of skeletons from graves 85 and 86 shows that they were located on their backs with legs bent at the knees. The heads were on a small earthen 'pillow' or were resting on the edge of the pit. For the skeleton of grave 81, the bones of the legs are slightly bent. The skeleton from grave 90 with a stone cross-shaped sceptre is assigned to this group in the half-sitting position. The skeleton from grave 23 was in a crouched position with a blockage on its right side (Fig. 8). The skeleton from the halfruined grave 52 is also included in this group, because of a stone bracelet located on the humerus (Fig. 9.1). Bracelets worn on the hands of the bu-

Fig. 4. Grave 79. ried were found in the Nalchik grave (Kruglov 1941. Figs. 33-34). The same bracelets was found from the I Khvalynsky burial ground (Agapov et al. 1990. 106, Fig. 10.6), the destroyed Ivanovsky burial ground (Morgunova 1979.17, Fig. 3.23-30), grave in Krivoluchye (Vasiliev 1981.106.1-2), which contained a sceptre similar to those of the Hvalynskaya culture. The reasons for the differences in the positions of skeletons are yet to be clarified, but the signs are characteristic of burial rituals from the Khvalynsko-Srednestnogovskoe time. The graves of the second group are noted in the central and eastern parts of the burial ground.

Despite the differences in the positions of the buried in the first and second groups in the Ekaterinovsky Cape burial ground, and some differences in the grave inventory, they are not entirely dissimilar to each other. There are cases when the skeletons of the first group were touched, but not destroyed, when arranging the graves of the second group. For

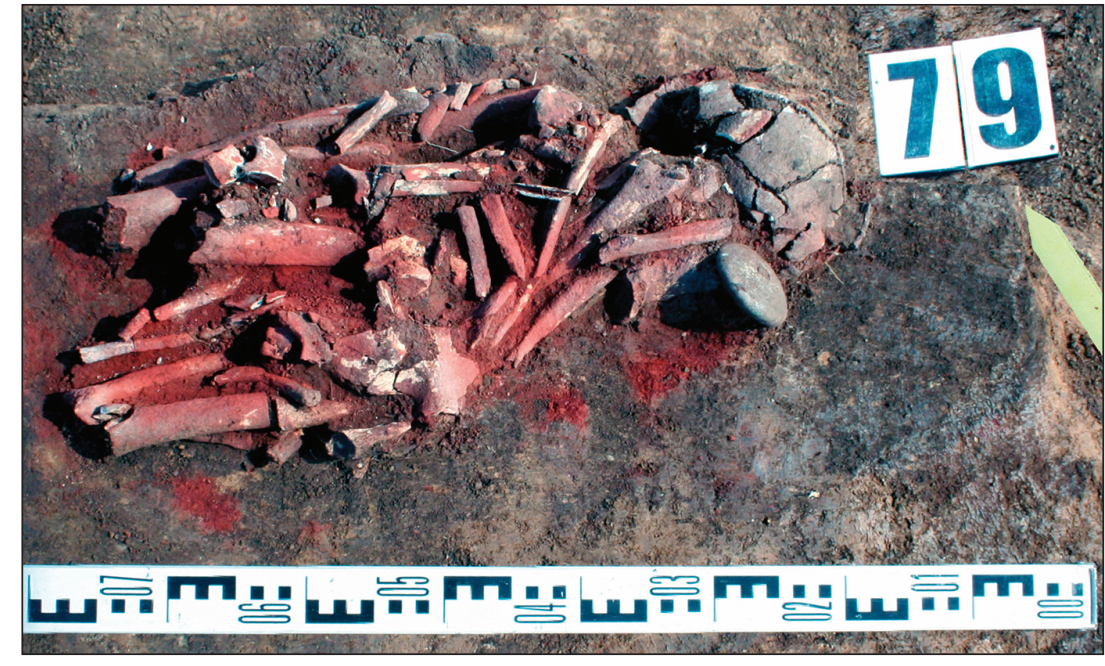


example, the crouched skeleton from grave 23 is close to the graves 24 and 25 (Fig. 8). So, the time difference between the construction of the graves of the first and second groups cannot be significant. It is thus impossible to exclude the possibility that these graves can belong to the same time period. The depth of the graves, the absence of a noticeable filling of the burial pit, the condition of the bones and the inventory are the same. For example, the cross-shaped sceptre from the half-head grave 90 is typologically close to the cross-shaped sceptre from grave 45 . The shell bead from the crouched grave 23 is not very different from similar beads from extended graves. Products made of tubular bones were found in the graves of both groups.

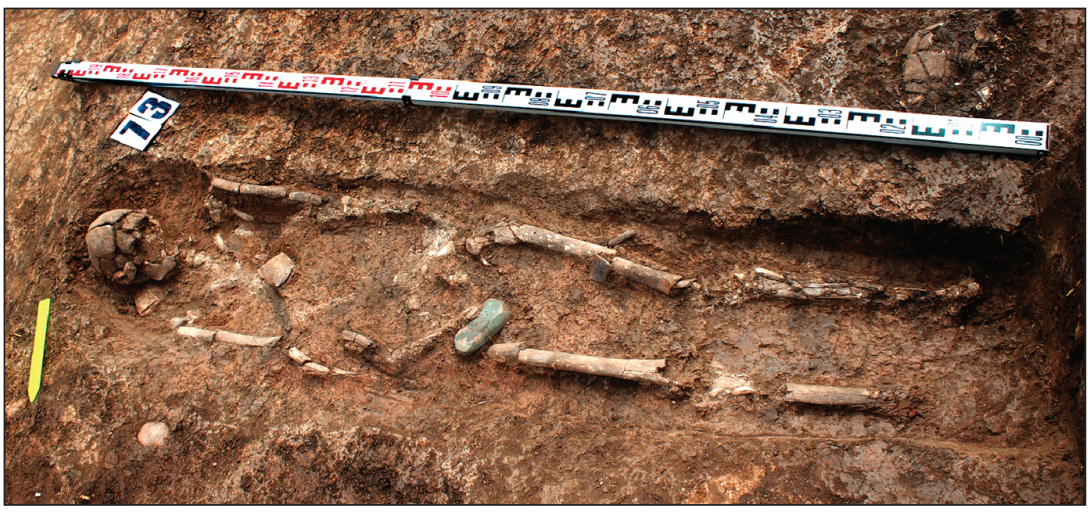

Fig. 5. Grave 73.

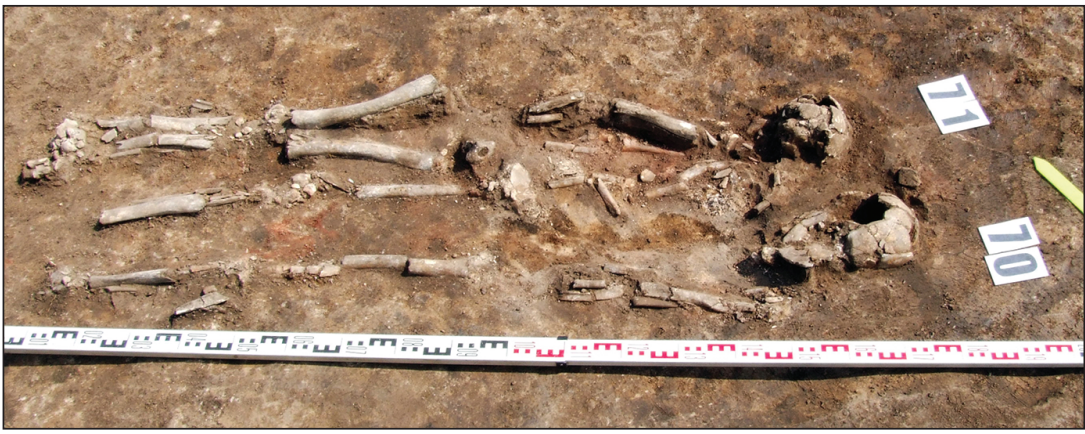

Fig. 6. Double grave 70-71.

It is more difficult to assign separate burials of skulls to one of these groups, which, as a rule, are not accompanied by inventory. Such burials may include one skull, two, or three.

Such graves are mainly localized in the central and eastern parts of the burial ground. The secondary burial ceremony was clearly manifested in grave 79, which consisted of compactly folded bones from two men and a woman covered with red ochre (Fig. 4). The grave was accompanied by a stone discoid sceptre (Fig. 9.2).

The burial ground contains mostly adult male and female graves, with few children. The anthropological study of skeletons is complicated by the poor preservation of bones and is not completed. However, for the most significant graves such definitions were made (Khokhlov 2018. 78). For grave 45 a graphic reconstruction of the skull was performed (KOrolev et al. 2018.299).

\section{The funeral inventory}

The distribution of inventory in graves is uneven. There is a large group of graves without inventory, and as a rule they are not ochre coloured or are only

slightly coloured. Such graves were located throughout the burial ground. More than half of the graves are with inventory, and they are often painted with ochre.

According to the total number of items found in the graves, beads made from Unio shells are the most numerous. These are disc-shaped with a hole in the centre and their size is $0.6-0.9 \mathrm{~cm}$. Beads were found in men's, women's and children's graves. In some graves, small beads were preserved in situ; judging by their location, they were sewn onto clothing. Sometimes in the graves there was one bead each, in others several dozen; for example, grave 49 had 27 beads, grave 40 had 261 beads, while grave 31 had more than a thousand beads (Fig. 10.1). Other items found in the graves are: pendants (Fig. 10.2), pierced seashells (Fig. 10.4-5), and beads made of brown and green stones (Fig. 10.3). Beads in graves are less common than adzes.

Graves with stone adzes are the most numerous in the burial ground. In one grave there can be up to four adzes. These are made of flint limestone, flint, and stones of green colour (Fig. 11) their size is from 5 to $19 \mathrm{~cm}$ in length. As a rule, adzes have a polished surface and are well sharpened, but there are also ones processed only with chips. Many adzes were 
broken during the commission of the burial rite, as represented by debris. Often they were broken by a strong strike. Fragments of broken adzes were found in the graves and cultural layer. Such actions are associated with the rite of spoilage of things recorded in the burial grounds of the Mariupol time at Sjezzhee (Vasiliev, Matveeva 1979.152) and Lipoviy gully (Vasiliev 1985.1112). Adzes are in the inventory of both private and extraordinary graves. Knife-shaped plates of flint and quartzite are from 0.6 to $3.5 \mathrm{~cm}$ in width and up to $18 \mathrm{~cm}$ in length. Plates with and without retouching were found in graves, both with ordinary and with 'prestigious' inventory (Fig. 12).

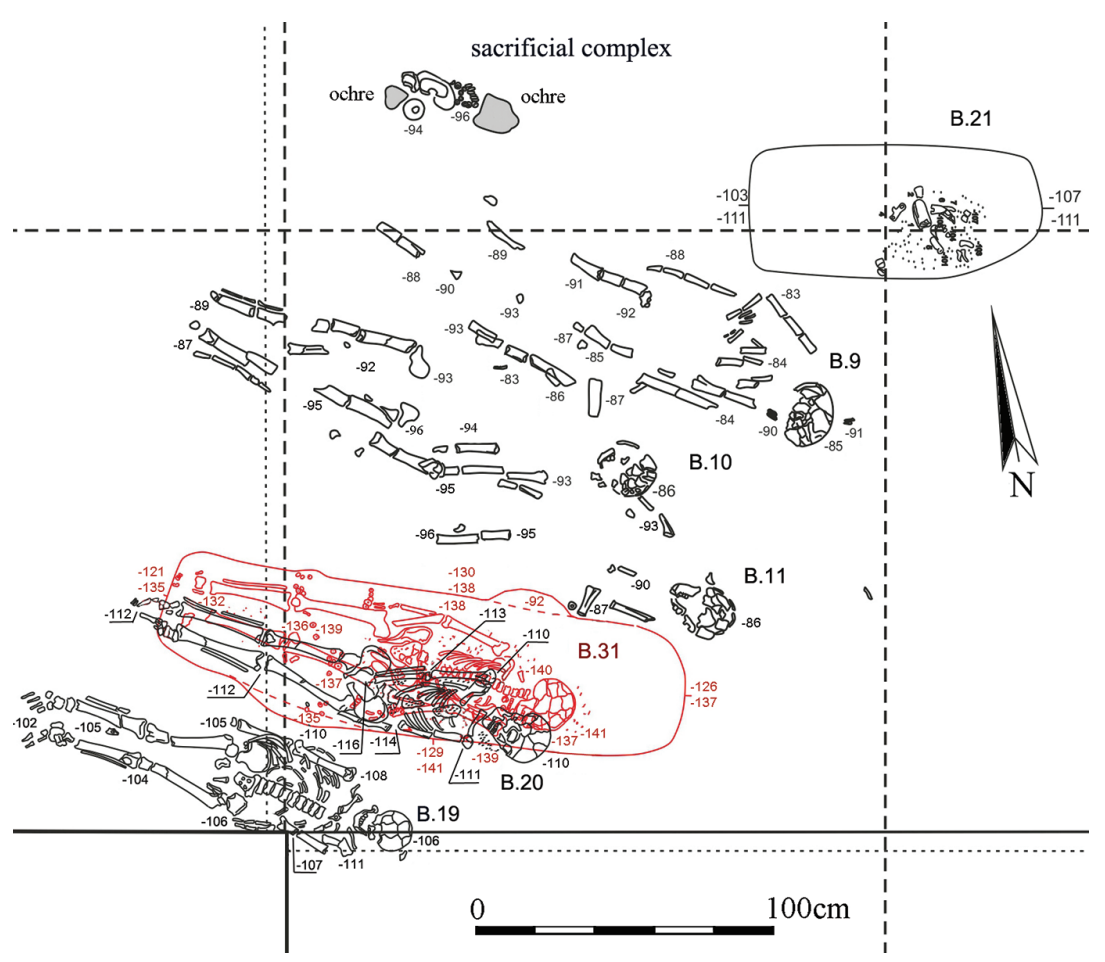

Fig. 7. The plan of graves 9-11, 19-21, 31 and the sacrificial complex.
Stone sceptres and rods made from horn were found in the graves with knives 45 and 46 (Fig. 13.2; 14). Stone products include small rings. They are often represented by fragments, but there are also whole copies (Fig. 13.1). There are single small pendants made of stone. In one case, a stone slab with an abrasive surface was found in grave 16 .

Products from boar tusks are quite numerous. These include large plaques of canines with and without holes at the ends, with ornament. A large group consists of plaques from the canine of a boar with cuts along the edges, holes and a protrusion (Figs. 15.1; 16.3). There are adornments of marmot teeth, which, apparently, were sewn onto clothing (Fig. 15.6-11). Marten fangs usually have cuttings on the root on one or two sides, but there are examples with holes and there are fangs without treatment (Fig. 15.25). Beaver's cutters often have transverse cuts near the ends. In the graves there are various products made of animal bones: plates with protrusions and holes, fragments of zoomorphic figures, rings of tubular bones, tubes (Fig. 15.12), daggers, pendants and large plates of horns. In the extraordinary grave 17 a hollow object carved from a horn was found, in which there were three wedge-shaped objects also made of a horn. This grave included a horn staff in the form of an elk's head, a large plate with holes from a boar's tusk, small bone plates and beads from shells. The large tusk of a boar with holes at its ends was located on the vertebrae of the deceased. Wands from the horn in the form of heads of birds, elks, and other animals, the form of which is difficult to determine, are of great interest. In grave 45 there were bones of a sacrificial domesticated animal, a young goat (Korolev et al. 2018.297). Bones of a

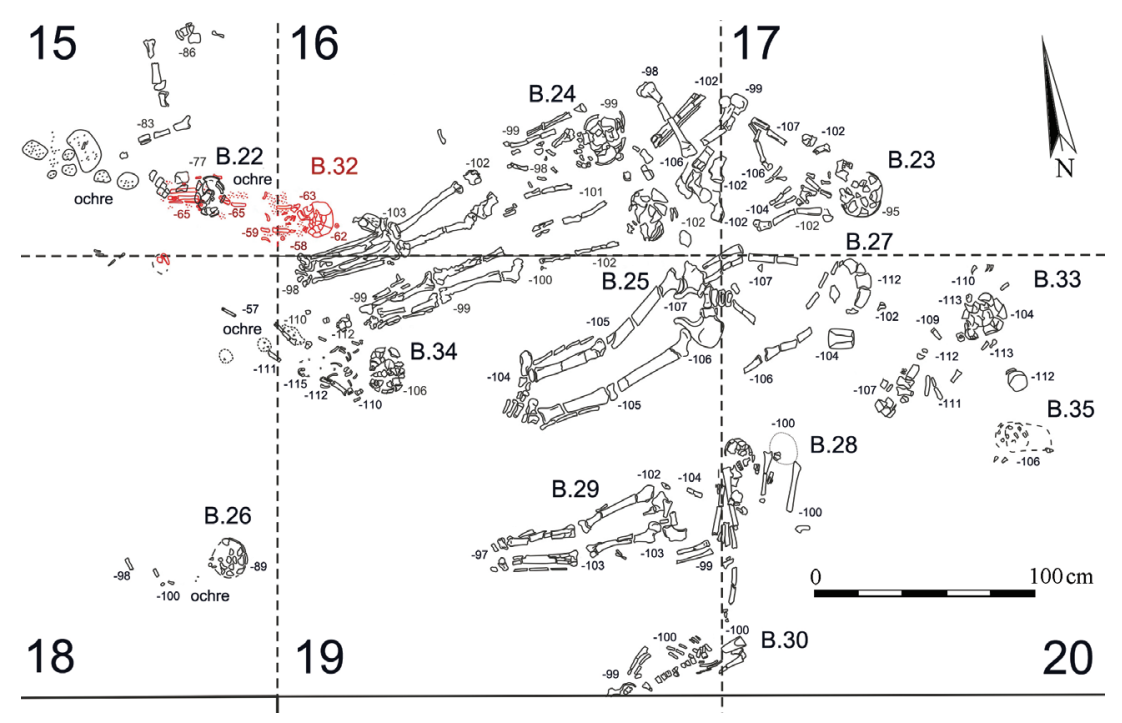

Fig. 8. The plan of graves 22-30, 32-35. 

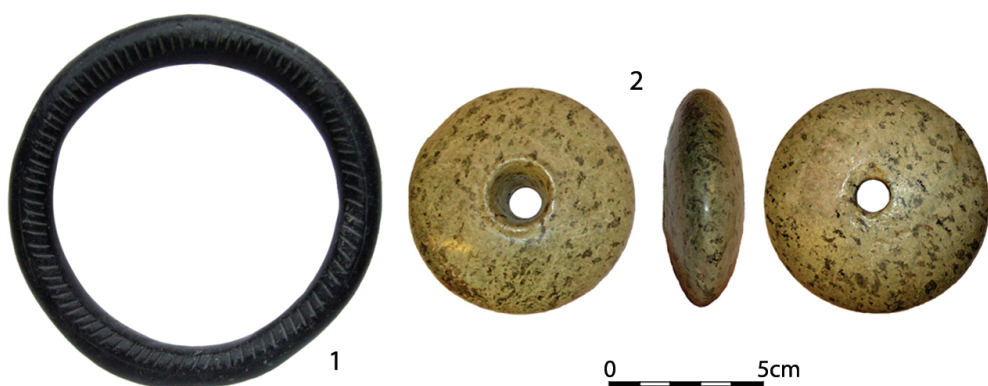

$5 \mathrm{~cm}$

Fig. 9. Stone ring-bracelet from grave 52 and a stone pommel mace from grave 79.

sheep and a horse were found in the cultural layer and in some graves. It is difficult to prove their direct connection to the graves, since the bones of animals could enter the filling of the pits from the cultural layer. The problem of horse domestication in the Eneolithic remains unresolved (Anthony 2007; Kosintsev, Kuznetsov 2013.405-408). Therefore, the question of whether horse bones found in a burial ground belong to domesticated animals or not remains open. According to the presence of 'prestigious' items and the amount of inventory in the burial ground, extraordinary graves were identified in the first group. Distinctive features are stone tops of sceptres, zoomorphic tops of wands from elk horn and other individual items.

In total, 15 stone sceptres were found in graves 18 , $40,45,46,52,69,71,76,79$, 90 , and 93 (Fig. 13.2). In grave 45 , three stone sceptres were found, i.e. a zoomorphic, cruciform, round-flattened and a rod of horn in the form of a bird's head. Also two sceptres were found aside from the graves as part of the sacrificial complexes. Zoomorphic wands or pommel hammers from horn were found in graves 19, 40, 45, and 46 (Fig. $14)$. Another such wand was found in the sacrificial complex near grave 76 (Fig. 16.1). Some of these products are poorly preserved, such as those from grave 55 , and it is possible that there were more zoomorphic products. In some cases, the reason for determining the originality of the grave was either the rarity or high number of items found there. For example, in grave 9 there was a bone dagger, marten

teeth, and a beaver's cutter. Grave 31 was made in a deep hole and contained a record number of shell beads, as well as pendants, bone rings and incisors of the marmot. In grave 41, polished rings of tubular bones, flint adzes, shell beads, and incisors of the marmot were found. In grave 74 there were two large horn plates on pelvic bones.

An important feature of the Ekaterinovsky Cape burial ground is the sacrificial sites and complexes, and these often contained ochre-coloured ceramics. The vessels were used for funeral feasts, they were exhibited in specially organized places near the graves, and often overlapped them. Places of increased concentration of ceramics were noted along the territory of the burial ground from east to west. The dishes were made of clay with an admixture of a crushed shell (Vasilyeva 2019.3340). The vessels had corolla with a specific thickening on the outer side - the 'collar' and the bottom of a rounded and flattened shape. The ornament is mainly made with comb and rope stamps; there are small holes and drawn lines (Fig. 17).

Sacrificial complexes do not include human bones and are usually located near the graves. They differ

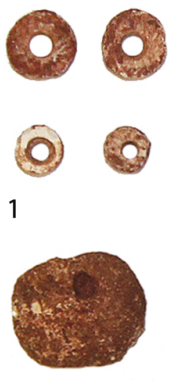

2

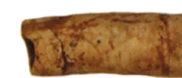

4

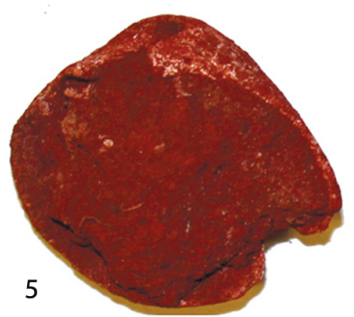

0
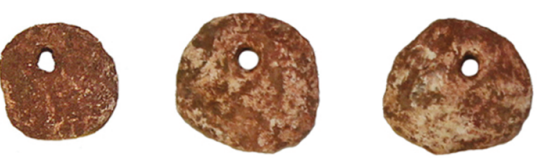

3
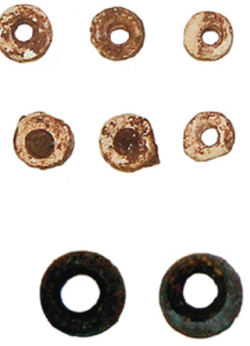

.



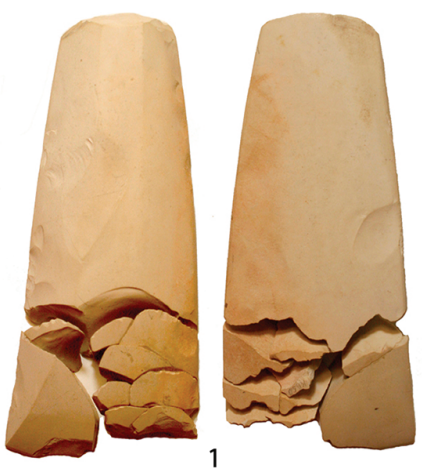
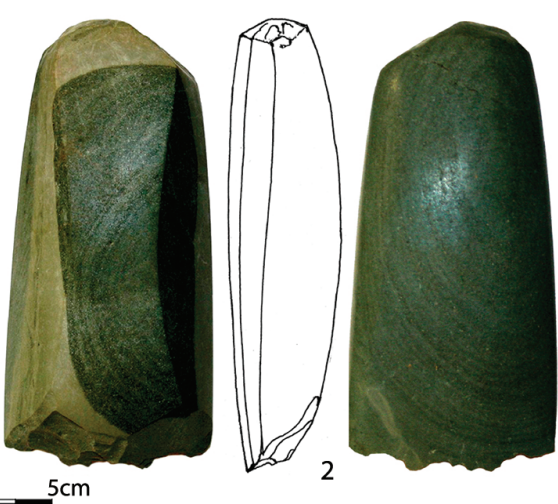

Fig. 11. Adzes. 1 grave 70; 2 grave 73.
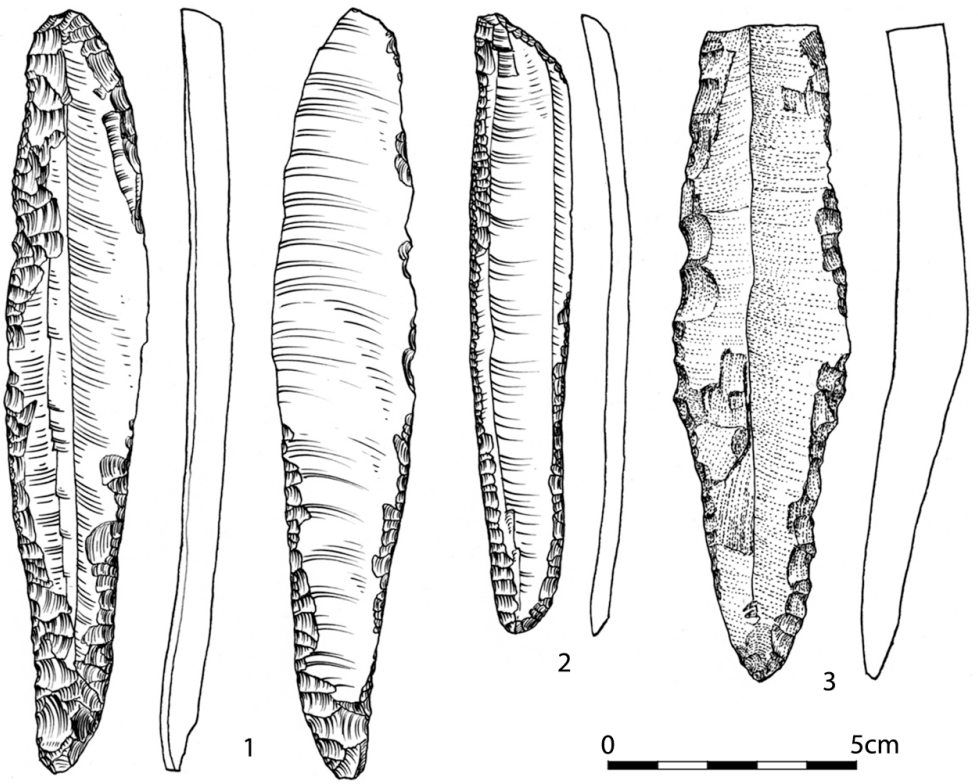

Fig. 12. Grave 46. 1-2 flint knives; 3 quartzite knife.

in the composition of their inventory, and sometimes contain items similar to those found in graves or include a set of original items. For example, in the square of 5 was found a number of things including pieces of broken stone scepter and beads made of shells. The complex, found in square 48 , consisted of a large, zoomorphic hammerhead from horn, a fragment of a second blade, a bone wedge, beaver incisors, and shell beads. These complexes are fully consistent with the sets of things from graves 40 and 45 . The complex of things found in square 74 includes two flint tips of darts with a notched base and knife-like plate-inserts. The tips are typologically close to the blanks of the tips from grave 86 of the second group, with these things being found together for the first time. Analysing the sacrificial complexes it is necessary to mention that in grave 45 , besides the sacrificial animal, the bones of the legs of other individuals were also found.

\section{Cultural affiliation, analogies and chronology}

The cultural affiliation of the burial ground is determined by the combination of signs of the grave. First of all we should mention that the first group of graves is of the Mariupolsky type, and this provides a reasonable basis for considering the framework of the Samara culture. The Neolithic or Eneolithic epoch is complicated. It has been found that there are no metal products for the early pastoralists of the Pricaspian, Samara and Khvalynsky, which is associated with the beginning of the Eneolithic in the Lower and Middle Volga. The materials found in the Ekaterinovsky Cape burial ground are similar to those studied in the Volga region in Sjezzhee (Vasiliev, Matveeva 1979). The main features of the burial rite (spine-stretched position, ochre, orientation in the eastern sector), the inventory (plates from boar's

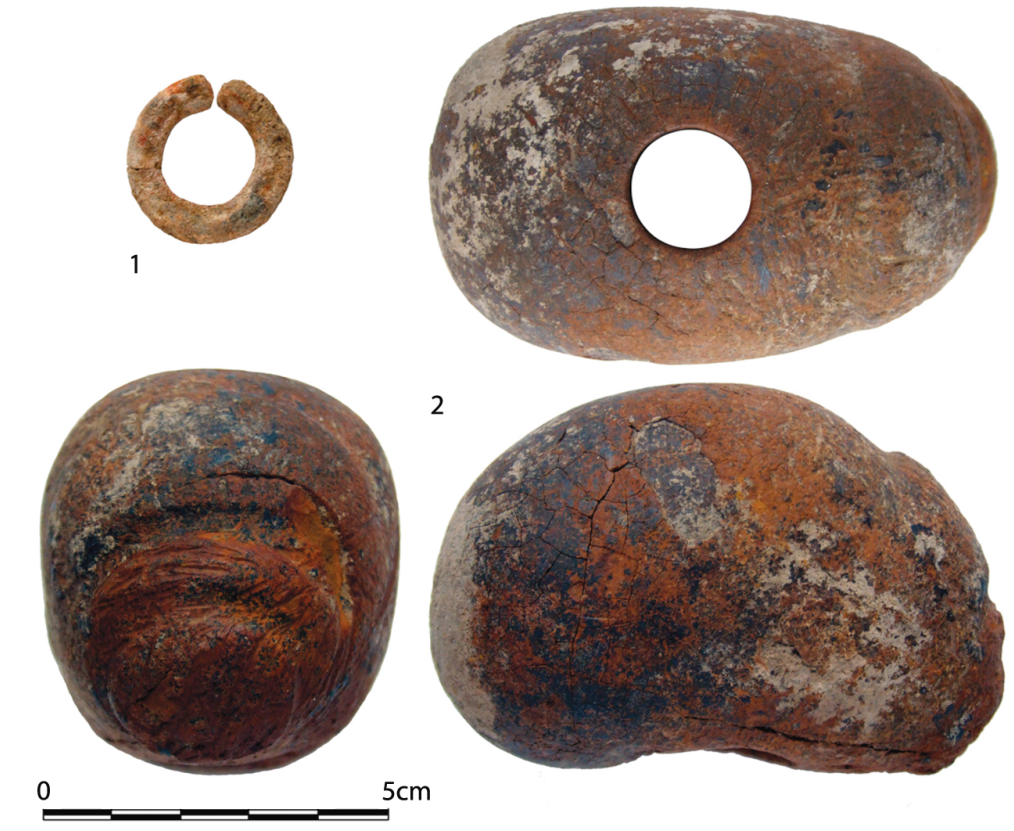

Fig. 13. 1 Stone ring, grave 58; 2 stone pommel sceptre, grave 46. 


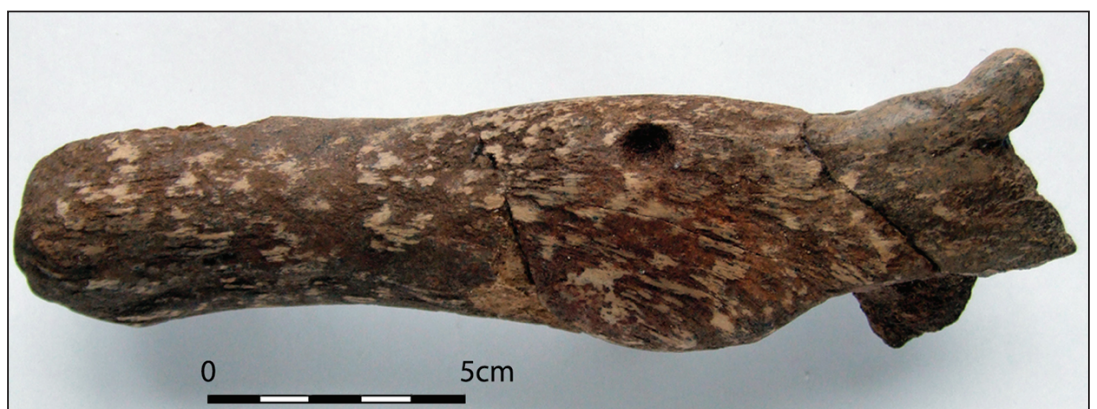

Fig. 14. Grave 46. A horn sceptre.

canine teeth, pendants made from animal teeth, bone products, shell and stone beads, knife-shaped plates, and in some cases sceptres) bring together the Ekaterinovsky Cape burial ground with the Mariupol (Makarenko 1933), Yasinovatsky (Telegin 1991), and Nikolsky burial grounds of Dnieper region (Telegin 1961.20-26). The second group of graves are more similar to Murzikhinsky burial ground (half-sitting burial in a pose, stone rings, leaf-shaped tips; Chizhevsky 2008.367-371) and I and II Khvalynsky burial ground (crouched on the back of the burial, ochre, sceptres with side ledges, stone bracelets, plates from boar's tusk, shell beads, tips with a truncated base, bone rings and tubules, knife-like plates of flint, small adzes; Agapov et al. 1990). Boar tusk pectoral, a bracelet ring are similar to the Nalchik burial ground (Kruglov et al. 1941). Stone bracelets, shell beads, lines, and pendants make the bu- rial ground more similar to the graves at Krivoluchje ( $\mathrm{Va}$ siliev 1981.106).

The operation time of the burial ground is pre-determined by close analogies and dates obtained from the bones of skeletons and fragments of ceramics. The date DeA-8214 $6442 \pm 34$ BP $(5470-5380 \mathrm{cal}$ $\mathrm{BC}$ at $1 \sigma)$ was obtained from a human tooth. This corresponds to the date obtained from fragments of ceramics from the sacrificial site of the burial ground (Korolev et al. 2019 29), and is close to the date of the human bone from grave 45 (Korolev et al. 2018.300). The dates obtained have a relatively narrow chronological range of approx. 5480-5219 cal BC. The dates obtained on human bones from the Ekaterinovsky Cape burial ground are similar to those for burial grounds at Vasilyevka 5, Nikolskoe, and Yasynuvatka (Kotova 2018.57-60). The main characteristics of the funeral rite and inventory also have the closest analogies with the materials of stage $1 \mathrm{~B}$ and the second stage of the Azov-Dnieper culture (Kotova 2002.25). But for a number of samples from human bones in the burial grounds of the Azov-Dnieper culture a reservoir effect is established, which can reach 400-500 years (Kotova 2018.58). Therefore, before making
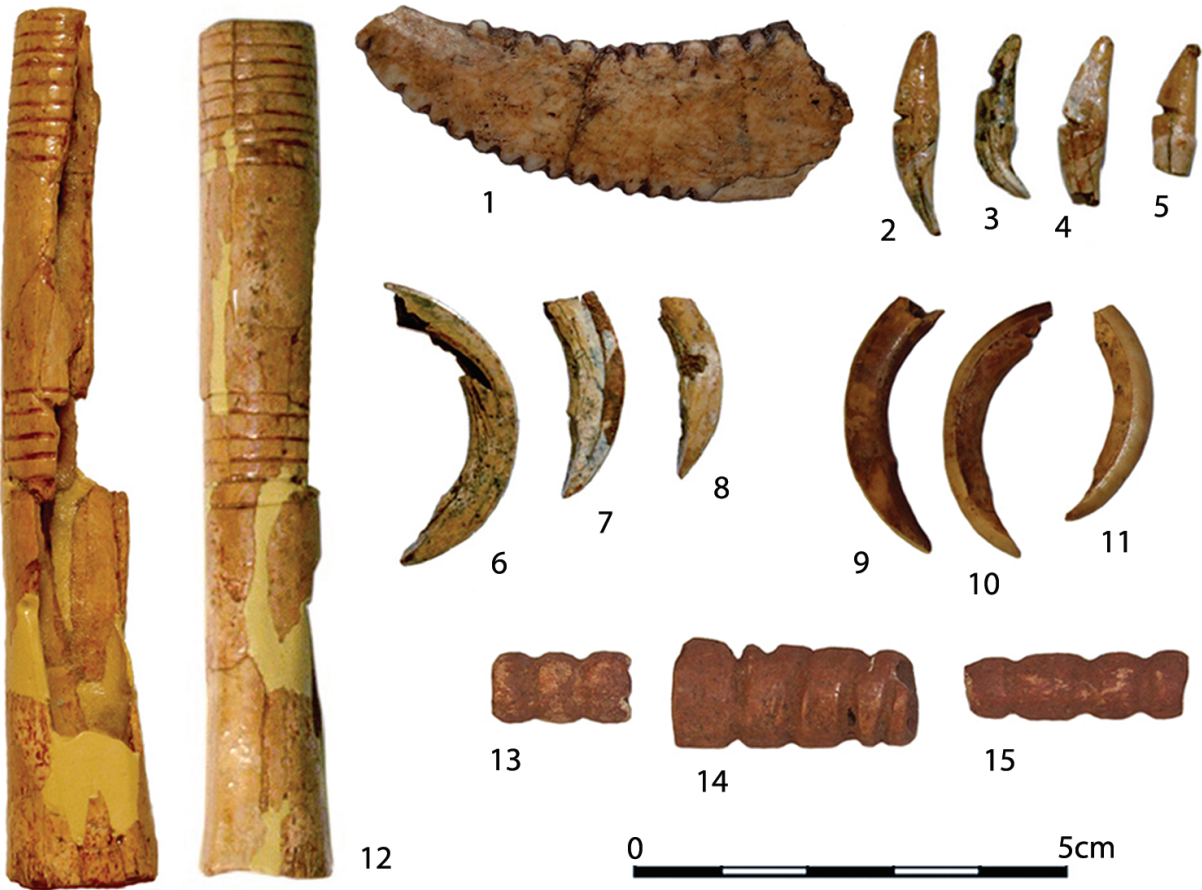

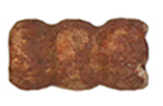

13

12

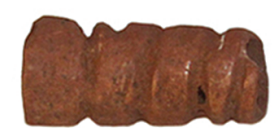

14

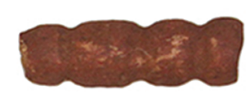

15 $5 \mathrm{~cm}$

Fig. 15. 1 The product from the tusk of a wild boar, grave 50; 2-5 decoration of tusks, martens, grave 70; 6-8 incisors of the marmot, grave 70; 9-11 grave 31; 12 bone tube, grave 70; 13-15 beads from tubular bone, grave 31. 

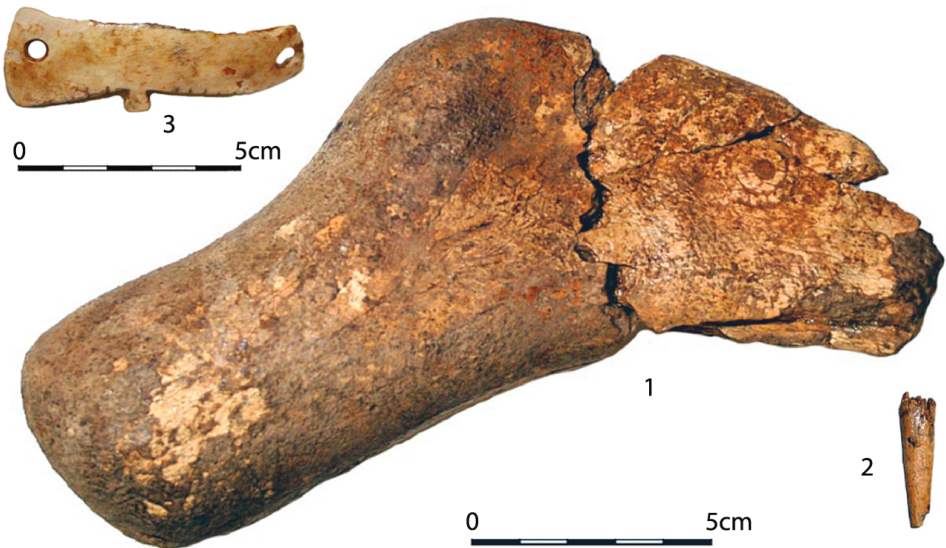

Fig. 16. Sacrificial complex: 1 Rod-hammer, 2 bone wedge. Grave 21: 3 boar's tusk plaque.

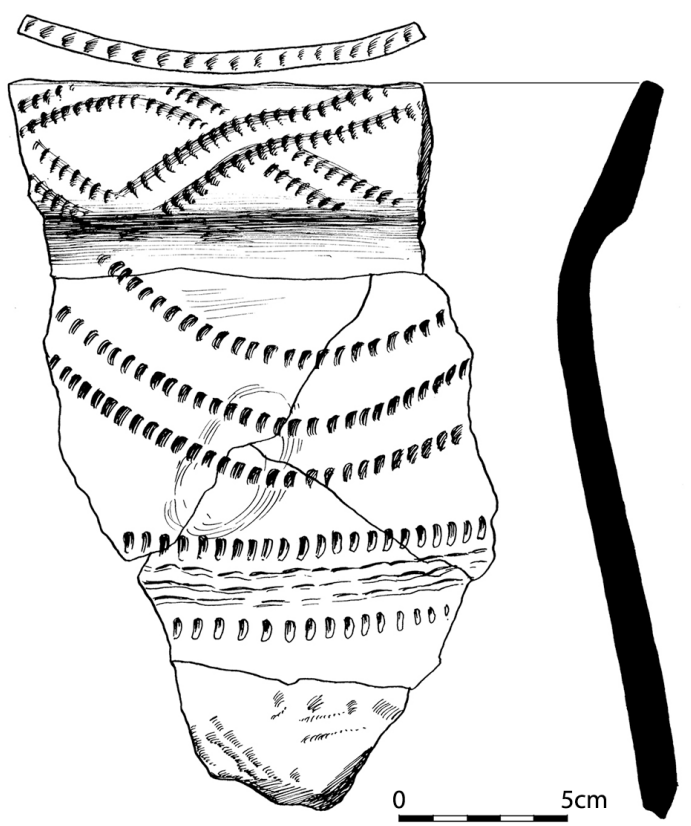

Fig. 17. Ceramics from a sacrificial place. any final conclusions it is necessary to find out the presence of a reservoir effect in the human bones found in the Ekaterinovsky Cape burial ground.

\section{Conclusion}

It should be emphasized that the significance of the Ekaterinovsky Cape burial ground is determined by a number of circumstances. A large number of graves and numerous funeral goods are a representative basis for analysis and analogies. Characteristic features of the funeral rite and inventory give grounds for its inclusion in the burial grounds of the Mariupol historical and cultural region. In the spatial aspect, the contacts of the population of the steppe Volga region with those of the Azov region and the Dnieper in the late Neolithic and early Eneolithic became clearer. The presence in the materials of the burial ground of crouched burials allowed us to combine the materials of the earlier period of the S'ezzhinsky type and the later Khvalynsky. This is an important chronological aspect of the study of this burial ground. The chronology of the burial ground is determined by the first radiocarbon dates, which allow it to be synchronized with stage $1 \mathrm{~B}$ and the second stage of the AzovDnieper culture.

\section{ACKNOWLEDGEMENTS}

The work was carried out with the support of state assignment No. 33.1907.2017/Pch. 


\section{Reference}

Agapov S. A., Vasiliev I. B., and Pestrikova V. I. 1990. Khvalynskiy eneoliticheskiy mogilnik. Saratovsky universitet. Saratov. (in Russian)

Anthony D. W. 2007. The Horse, the Wheel and Language: How Bronze-Age Riders from the Eurasian Steppes Shaped the Modern World. Princeton University Press. Princeton and 0xford.

Chizhevsky A. A. 2008. Pogrebeniya epohi eneolita Murzihinskogo II mogilnika. In A. P. Derevyanko, N. A. Makarov (eds.), Trudy II (XVIII) Vserossiyskogo arkheologicheskogo s'ezda v Suzdale 2008 g. I. Nauka Publ. Moscow: 367-371 (in Russian)

Khokhlov A. A. 2018. Predvaritelnye rezultaty issledovaniya paleoantropologicheskikh materialov gruntovogo nekropolya Ekaterinovsky mys (po raskopkam 2014- 2017). In XXI Uralskoe soveschanie. Materialy vserossiyskoy nauchnoy konferenscii. Samarskiy Gosudarstvennyy Sotsial'no-Pedagogicheskiy Universitet. Samara: 40-42. (in Russian)

Kochkina A. F. 2015. Razvedochnye raboty v Samarskoi oblasti. Arkheologicheskie otkrytiya 2010-2013. Institut Archeologii Rossiyskaya akademiya nauk. Moscow: 495496. (in Russian)

Korolev A. I., Kochkina A. F., Stashenkov D. A., Khokhlov A. A., and Roslyakova N. V. 2018. The Unique Burial of the Ekaterinovsky Cape Early Eneolithic Cemetery in the Middle Volga Region. In Late Prehistory of Eurasia: Social Models and Cult Practices. Stratum plus N. 2. Archaeology and Cultural Anthropology. St. Petersburg-KishinevOdessa-Bucharest: 285-302.

Korolev A. I., Kochkina A. F., and Stashenkov D. A. 2019. Keramika gruntovogo mogil'nika Yekaterinovskiy mys (po materialam raskopok (2013-2016 gg). Povolzhskaya arkheologiya 1(27): 18-33. (in Russian with English summary) https://doi.org/10.24852/2019.1.27.18.32

Kosintsev P., Kuznetsov P. 2013. Comment on "The Earliest Horse Harnessing and Milking". In Tiragetia. Archaeologie Istorie Antică. Serie Nouă. Vol. VII (XXII). Muzeul Naţional de Istorie a Moldovei. Chişinău: 405-408.
Kotova N. S. 2002. Neolitizasciya Ukrainye. Institut Archeologii Natsional'na Akademiia nauk Ukrainny. Lugansk. (in Russian)

2018. Revisiting the Neolithic chronology of the Dnieper steppe region with consideration of a reservoir effect for human skeletal material. Sprawozdania arheologiczne 70: 47-66.

https://doi.org/10.23858/SA70.2018.003

Kruglov A. P., Piotrovsky B. B., and Podgaetsky G. V. 1941. Mogilnik v g. Nalchike. Materialy $i$ issledovaniya po arheologii SSSR: 67-147. (in Russian)

Makarenko M. 1933. Mariupolsky mogilnik. Vseukrainskiy arkheologicheskiy komitet (VUAK). Kiev. (in Russian)

Morgunova N. L. 1979. Ivanovskay duna na reke Tok v Orenburgskoy oblasti. Drevnya istoriya Povolzhya. Kuibyshev: 15-24. (in Russian)

Telegin D. Ya. 1961. Nikolsky mogilnik epohi neolita-medi v Nadporozzhie. Kratkie soobsheniya Instituta Arheologii 11: 20-26. (in Russian)

1991. Neoliticheskye mogilniki Mariupolskogo tipa. Naukova dumka. Kiev. (in Russian)

Vasiliev I. B. 1981. Eneolit Povolzhya (step and lesostep). Izdania Kuibyshevkog Gosudarstvenog Univerzita. Kuibyshev. (in Russian)

1985. Mogilnik mariupolskogo vremeni Lipovy Ovrag na severe Saratovskoy oblasti. Drevnosti Srednego Povolzhya. Kuibyshev: 3-19. (in Russian)

Vasiliev I. B., Matveeva G. I. 1979. Mogilnik u s. Syezzhee na r. Samare. Sovetskaja arheologija 4: 147-166. (in Russian)

Vasilyeva I. N. 2019. 0 tekhnologii izgotovleniya keramiki Eneoliticheskogo mogil'nika Yekaterinovskiy mys. Povolzhskaya arkheologiya 1(27): 33-47. (in Russian with English summary) https://doi.org/10.24852/2019.1.27.33.46

\section{back to contents}

